\title{
Phylogenetic placement of Neorhamphoria garethjonesii gen. et sp. nov. (Tubeufiales, genus incertae sedis)
}

\author{
Boonmee $S^{1}$, Ekanayaka $\mathrm{AH}^{1,3}$, Hyde, $\mathrm{KD}^{1}$, Hüseyin $\mathrm{E}^{2}$, Ekici $\mathrm{K}^{2}$ and Selçuk \\ $\mathbf{F}^{2}$ \\ ${ }^{1}$ Center of Excellence in Fungal Research, Mae Fah Luang University, Chiang Rai 57100, Thailand \\ ${ }^{2}$ Department of Biology, Arts and Sciences Faculty, Ahi Evran University, Kirşehir, Turkey \\ ${ }^{3}$ Key Laboratory for Plant Diversity and Biogeography of East Asia, Kunming Institute of Botany, Chinese \\ Academy of Science, Kunming 650201, Yunnan, China
}

Boonmee S, Ekanayaka AH, Hyde KD, Hüseyin E, Ekici K, Selçuk F 2016 - Phylogenetic placement of Neorhamphoria garethjonesii gen. et sp. nov (Tubeufiales, genus, incertae sedis). Mycosphere 7 (9), 1447-1457, Doi 10.5943/mycosphere/7/9/16

\begin{abstract}
Neorhamphoria garethjonesii is introduced for a new genus and species with apothecial ascomata growing on dead wood of Cotoneaster nummularius (Rosaceae) in terrestrial habitats. Neorhamphoria is characterized by its dark apothecial ascomata, broad cellular pseudoparaphyses, with bitunicate, broad-clavate asci, and hyaline, muriform ascospores. Molecular phylogenetic analyses of combined LSU, SSU and TEF1 $\alpha$ sequence data indicate that Neorhamphoria belongs in Dothideomycetes and is related to Tubeufiales. Morphologically, Neorhamphoria differs from all genera of Tubeufiales and thus we treat it as a new genus in Tubeufiales, genus incertae sedis.
\end{abstract}

Keywords - apothecial ascomata - bitunicate asci - lignicolous, molecular phylogeny muriform ascospores

\section{Introduction}

Turkey has a very diverse flora, and the higher plants of Turkey have been wellstudied, but the mycota has not been extensively investigated and most of the studies deal with macromycetes, generally the agaricoid fungi. Even though there has been no proper investigation of the Turkish micromycete mycota, the ascomycetous microfungi on higher plants of Turkey have been well-studied, but most of the studies deal with Erysiphales and a few with Diaporthales, Xylariales and other orders (Karaca 1961, Göbelez 1963, Baydar 1975, 1982, Güven \& Tamer 1993). During the last 15 years, research on ascomycetous micromycetes in the country has intensified (Hüseyinov \& Selçuk 2000, 2001, Mel'nik et al. 2004, Hüseyin \& Y1ldizbaş 2005, Hüseyin et al. 2006, 2009, 2016, Hüseyin et al. 2006, 2009, 2016, Selçuk et al. 2010, Bülbül et al. 2011, Bülbül \& Hüseyin 2013, Selçuk \& Hüseyin 2014). 
This present taxon was collected during a trip to Kervansaray Mountain, Kırşehir Province, Central Anatolian Peninsula. This mountain lies in the Irano-Turanian phytogeographic region (Hamzaoğlu 1996). The species is somewhat reminiscent of Rhamphoria (Niessl 1876), with the type R. delicatula Niessl, from rotting wood of an unidentified plant from Brünn, Moravia, in the Czech Republic.

Tubeufiales comprises saprobic species commonly occurring on dead or decaying wood from diverse ecological distributions in terrestrial and aquatic habitats (Goh et al. 1998, Réblová \& Barr 2000, Promputtha \& Miller 2010, Boonmee et al. 2011, 2014a, b, Hyde et al. 2013, 2016, Rageshkumar \& Sharma 2013). Currently, this order includes two families (Tubeufiaceae and Weisneriomycetaceae) and 23 genera of sexual and asexual morphs (Boonmee et al. 2014, Suetrong et al. 2014, Doilom et al. 2017). Its sexual morphs are characterized by light or dark, globose to subglobose, superficial ascomata, bitunicate asci, coloured or hyaline ascospores with transversely multi-septate, or muriform ascospores e.g. Boerlagiomyces (Crane et al. 1998, Doilom et al. 2017). Their asexual morphs are hyphomycetous, characterized by helicosporous, chlamydosporous and phragmosporous conidia and they are commonly found in aquatic habitat. Neorhamphoria garethjonesii also shares some features with members of Tubeufiales in its saprobic lifestyle, it occurrence on woody substrates and in having muriform ascospores.

In this study, our blasts of LSU, SSU and TEF1 $\alpha$ sequence data indicated that this taxon belongs to Dothideomycetes with a loose relationship with tubeufiaceous species. Based on morphological characters and multigene phylogenetic analysis, Neorhamphoria is established as a new genus in Tubeufiales, genus incertae sedis.

\section{Materials \& Methods}

Sample collection, morphological studies and isolation of fungi

The fungal specimen was collected in 2012 from Turkey. The identification of the host plant was made using the "Flora of Turkey and East Aegean Islands" (Davis 1967). Micro-morphological studies were carried out following the procedures outlined in Boonmee et al. (2014a, b). Type specimen and ex-type living culture are deposited Mae Fah Luang University Collections (MFLU and MFLUCC), Chiang Rai, Thailand and the Ahi Evran University, Arts and Sciences Faculty, Department of Biology, in Kırşehir Province of Turkey. Faces of fungi (FOF) and Index Fungorum (IF) numbers are provided as explained in Jayasiri et al. (2015) and Index Fungorum (Kirk 2016).

Single ascospore isolation was performed following the technique demonstrated in Chomnunti et al. (2014). Germinated ascospores were transferred to fresh malt extract agar (MEA, Difco Laboratories, Detroit, Michigan, USA) and grown at $28^{\circ} \mathrm{C}$ for one month. Culture morphological characters were examined after one month.

\section{Molecular procedures}

Fungal colonies were scraped from surface mycelia after one month. DNA extraction, PCR amplification and sequences were performed under the conditions described in Hyde et al. (2016). The new sequences conducted in this study were blasted to check for related taxa in GenBank database (www.ncbi.nlm.nih.gov/blast/), which indicated that this fungus belonged to Dothideomycetes.

Phylogenetic analyses

Our new strain and closely related taxa from recent relevant publications (Boonmee et al. 2011, 2014a, b, Hyde et al. 2013, 2016, Suetrong et al. 2014, Wijayawardene et al. 2014, 
Hongsanan et al. 2015, Doilom et al. 2017, Pratibha et al. 2015) were used in the phylogenetic analysis. Analyses of combined LSU, SSU and TEF1 $\alpha$ datasets were carried out to establish the placement of the new taxon. Multiple alignments were performed with the online program MAFFT v.7 (Katoh \& Standley 2013) and manually edited using BioEdit 7.0.5.3 (Hall 1999). Phylogeny online program "ALTER" was used to format fasta dataset for RAxML analysis (Glez-Peña et al. 2010). Maximum likelihood (ML) analysis was generated in online program "RAxML-HPC BlackBox tool" on the CIPRES 3.3 web portal (Miller et al. 2010), following the default setup. RAxML rapid bootstrapping and subsequent ML search used distinct model/data partitions with joint branch length optimization, executing 1,000 rapid bootstrap inferences and thereafter a thorough ML search. All free model parameters were estimated by RAxML and ML estimate of 25 per site rate categories. The final ML search was evaluated and optimized under GTRGAMMAI model.

Table 1. The new taxon used for phylogenetic analysis with GenBank accession numbers of LSU, SSU and TEF1 $\alpha$ sequence data. New sequences are in bold.

\begin{tabular}{|c|c|c|c|c|}
\hline \multirow{2}{*}{ Species } & \multirow{2}{*}{ Voucher } & \multicolumn{3}{|c|}{ GenBank Accession number } \\
\hline & & LSU & SSU & 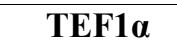 \\
\hline Acanthohelicospora pinicola & MFLUCC10-0116 & KF301534 & KF301542 & KF301555 \\
\hline Acanthostigma chiangmaiensis & MFLUCC10-0125 & JN865197 & JN865185 & KF301560 \\
\hline Aliquandostipite khaoyaiensis & CBS 118232 & GU301796 & AF201453 & GU349048 \\
\hline Apiosporina collinsii & CBS 118973 & GU301798 & GU296135 & GU349057 \\
\hline Boerlagiomyces macrospora & MFLUCC12-0388 & KU764712 & KU712475 & KU872750 \\
\hline Botryosphaeria dothidea & CBS 115476 & DQ678051 & DQ677998 & DQ767637 \\
\hline Botryosphaeria ribis & CBS 115475 & DQ678053 & DQ678000 & DQ677893 \\
\hline Botryosphaeria stevensii & CBS 431.82 & DQ678064 & DQ678012 & DQ677907 \\
\hline Chaetothyriothecium elegans & СРC 21375 & KF268420 & - & - \\
\hline Chlamydotubeufia huaikangplaensis & MFLUCC10-0926 & JN865198 & JN865186 & - \\
\hline Chlamydotubeufia khunkornensis & MFLUCC10-0118 & JN865190 & JN865178 & KF301564 \\
\hline Clavatispora thailandica & MFLUCC10-0107 & KF770458 & KF770457 & KF770459 \\
\hline Dendrographa decolorans & DUKE 0047570 & AY548815 & AY548809 & DQ883725 \\
\hline Neorhamphoria garethjonesii & MFLUCC16-0210 & $* * * * * *$ & $* * * * * *$ & $* * * * * *$ \\
\hline Guignardia citricarpa & CBS 102374 & GU301815 & GU296151 & GU349053 \\
\hline Helicoma khunkornensis & MFLUCC10-0119 & JN865191 & JN865179 & - \\
\hline Helicoma siamense & MFLUCC12-0563 & KU764713 & KU712479 & KU872751 \\
\hline Helicoma siamense & MFLUCC10-0120 & JN865192 & JN865180 & KF301558 \\
\hline Homortomyces combreti & СРC 19808 & JX517291 & - & - \\
\hline Homortomyces tamaricis & MFLUCC13-0441 & KF537345 & - & - \\
\hline Hysteropatella elliptica & CBS 935.97 & DQ767657 & EF495114 & DQ767640 \\
\hline Jahnula aquatic & R68-1 & EF175655 & EF175633 & - \\
\hline Lichenoconium aeruginosum & JL359 09 & HQ174269 & HQ174268 & - \\
\hline Lichenoconium erodens & JL363 09 & HQ174267 & HQ174266 & - \\
\hline Lichenoconium lecanorae & JL382 10 & HQ174263 & HQ174262 & - \\
\hline Lichenoconium usneae & JL352 09 & HQ174265 & HQ174264 & - \\
\hline
\end{tabular}


Table 1 continued

\begin{tabular}{llccc}
\hline \multicolumn{1}{c}{ Species } & \multicolumn{1}{c}{ Voucher } & \multicolumn{3}{c}{ GenBank Accession number } \\
\cline { 3 - 5 } & & LSU & SSU & TEF1a \\
\hline Macrophomina phaseolina & CBS 227.33 & DQ678088 & DQ678037 & DQ677929 \\
Manglicola guatemalensis & BCC 20079 & FJ743449 & FJ747443 & - \\
Manoharachariella tectonae & MFLUCC12-0170 & KU764705 & - & KU872762 \\
Microthyrium microscopicum & CBS 115976 & GU301846 & GU296175 & GU349042 \\
Natipusilla bellaspora & PE91-1b & JX474864 & JX474869 & - \\
Natipusilla decorospora & A236-1a & HM196369 & HM196376 & - \\
Parawiesneriomyces yzygii & CPC 26528 & KX228339 & - & - \\
Patellaria atrata & CBS 958.97 & GU301855 & GU296181 & GU349038 \\
Phaeotrichum benjaminii & CBS 541.72 & AY004340 & AY016348 & DQ677892 \\
Pseudogliophragma indicum & MTCC 11985 & KM052851 & KM052852 & - \\
Saccharata proteae & CBS 115206 & GU301869 & GU296194 & GU349030 \\
Sympoventuria capensis & CBS 120136 & DQ885906 & KF156094 & - \\
Thaxteriellopsis lignicola & MFLUCC15-0898 & KU764711 & KU712474 & KU872749 \\
Trichodelitschia bisporula & CBS 262.69 & GU348996 & GU349000 & GU349020 \\
Trichodelitschia munkii & Kruys 201 UPS & DQ384096 & DQ384070 & - \\
Tubeufia chiangmaiensis & MFLUCC11-0514 & KF301538 & KF301543 & KF301557 \\
Tubeufia javanica & MFLUCC12-0545 & KJ880036 & KJ880035 & KJ880037 \\
Tubeufia tectonae & MFLUCC12-0392 & KU764706 & KU712460 & KU872763 \\
Venturia inaequalis & CBS 594.70 & GU301879 & NG_016539 & GU349022 \\
Wiesneriomyces conjunctosporus & BCC40633 & KJ435455 & KJ425442 & - \\
Wiesneriomyces laurinus & BCC18609 & KJ425459 & KJ425443 & - \\
Zeloasperisporium siamemse & IFRDCC2194 & JQ036228 & JQ036223 & - \\
\hline
\end{tabular}

Bayesian command was generated using FaBox 1.14 (Villesen 2007). Bayesian posterior probability analysis was carried out under MrBayes 3.2.6 on the XSEDE at the CIPRES web portal (Ronquist \& Huelsenbeck 2003). The parameter setting of 2 parallel runs, 4 chains, run for 4,000,000 generations, sample frequency every 1,000 generations and all other parameters were left as default. The $50 \%$ majority rule consensus tree was created from the remaining trees and illustrated in Treeview (Page 1996). The sequences obtained in this study are deposited in GenBank (Table 1). The final alignment was deposited in TreeBASE submission no. 20355 (http://www.treebase.org).

\section{Results}

\section{Phylogenetic study}

The dataset comprising 48 taxa with analysis of combined LSU, SSU and TEF1 $\alpha$ sequence data and indicated that the new taxon belonged in Dothideomycetes. The alignment had 1403 distinct alignment patterns and the ML tree received the best scoring tree with a final $\ln$ value of -22896.365251 as illustrated in Fig. 1. The new genus Neorhamphoria clustered close to the Tubeufiales clade with good support values (74\% BS and >95 PP).

\section{Taxonomy}

Neorhamphoria Boonmee, E. Hüseyin \& F. Selçuk, gen. nov. 
Index Fungorum number: 552704; Facesoffungi number: 02823

Etymology - The generic epithet 'Neorhamphoria' refers to its likeness to Rhamphoria.

Saprobic on dead wood in terrestrial habitat. Sexual morph: Ascomata apothecia, cupshaped, superficial, solitary to grouped, black. Receptacle pulvinate, disc convex, disc and the margins are black. Exciple peridium consisting of thick-walled, pigmented, isodiametric cells. Hymenium upper part blackish brown and lower part is hyaline. Hamathecium comprising 2 $\times 3 \mu \mathrm{m}$ wide, numerous, cylindrical, broad cellular pseudoparaphyses, anastomosed, constricted septate, hyaline, apical pigmented, exceeding asci in length, apices are glued together to develop epithecium. Asci 8-spored, bitunicate, saccate to broad-clavate, broadly rounded at apex, non-amyloid, with a short bifurcate pedicel or apedicellate. Ascospores overlapping 2-3-seriate, partially overlapping, obovoid or elliptic with broadly to narrow rounded ends, initially 1 -septate at immature, becoming phragmosporous to muriform at maturity, 3-transversely septate, with 1-2-vertical septate, hyaline, smooth-walled. Asexual morph: Undetermined as did not sporulate in culture.

Neorhamphoria garethjonesii Boonmee, E. Hüseyin \& F. Selçuk, sp. nov.

Index Fungorum number: 552703; Facesoffungi number: 02824

Figs 2-3

Etymology - The specific epithet 'garethjonesii' is name in honour of E.B. Gareth Jones in recognition of his contributions to mycology.

Holotype - MFLU16-2859

Saprobic on dead wood of Cotoneaster nummularius Fisch. \& C. A. Mey., in terrestrial habitats. Sexual morph: Ascomata 179-199 $\mu \mathrm{m}$ high $\times 163-322 \mu \mathrm{m}$ diam. $(\bar{x}=$ $188.5 \times 257 \mu \mathrm{m}, \mathrm{n}=3$ ), apothecia, cup-shaped, superficial, solitary to grouped, black. Receptacle pulvinate, disc convex, disc and the margins are black. Exciple peridium $21 \times 30$ $\mu \mathrm{m}$ wide consisting of thick-walled, pigmented, isodiametric cells. Hymenium upper part blackish brown and lower part is hyaline. Hamathecium comprising $2 \times 3 \mu \mathrm{m}$ wide, numerous, cylindrical, broad cellular pseudoparaphyses, anastomosed, constricted septate, hyaline, apical pigmented, exceeding asci in length, apices are glued together to develop epithecium. Asci 74-110 × 21-29 $\mu \mathrm{m}(\bar{x}=88 \times 24.5 \mu \mathrm{m}, \mathrm{n}=20)$, 8-spored, bitunicate, saccate to broad-clavate, broadly rounded at apex, non-amyloid, with a short bifurcate pedicel or apedicellate. Ascospores 20-28 $\times 9-13 \mu \mathrm{m}(\bar{x}=25 \times 11 \mu \mathrm{m}, \mathrm{n}=20)$, overlapping 2-3seriate, partially overlapping, obovoid or elliptic with broadly to narrow rounded ends, initially 1-septate at immature, becoming phrgmosporous to muriform at maturity, 3transversely septate, with 1-2-vertical septate, hyaline, smooth-walled. Asexual morph: Undetermined as did not sporulate in culture.

Culture characteristics - Ascospores germinating on MEA within $12 \mathrm{~h}$ and spores changed to brown with germ tubes produced from each cell. Colonies on MEA slow growing, reaching $5 \mathrm{~mm}$ diam. in 2 week at $28{ }^{\circ} \mathrm{C}$, low convex, slightly effuse hairy, fimbriate edge, aerial mycelium radiating outwards, partially superficial, and partially immersed mycelium, cream to yellowish, not sporulate on culture at 30-45 days.

Material examined - TURKEY, Kurşehir Province, Boztepe district, mountain ligth forest, on dead wood of Cotoneaster nummularius Fisch. \& C. A. Mey. (Rosaceae), $1370 \mathrm{~m}$, $39^{\circ} 13^{\prime} 313^{\prime \prime}$ N, 341' $434^{\prime \prime}$ E, 2 December 2012, E. Hüseyin (KE 201, holotype; MFLU162859 , isotype) - ex-type living culture, MFLUCC16-0210.

Notes - The black apothecial ascomata, thin inner layer of bitunicate asci and muriform ascospores found in Neorhamphoria garethjonesii are similar to these characters in some genera (e.g. Murangium and Tryblidaria) of Patellariaceae (Yacharoen et al. 2015). Neorhamphoria garethjonesii differs from these genera in having hyaline muriform 


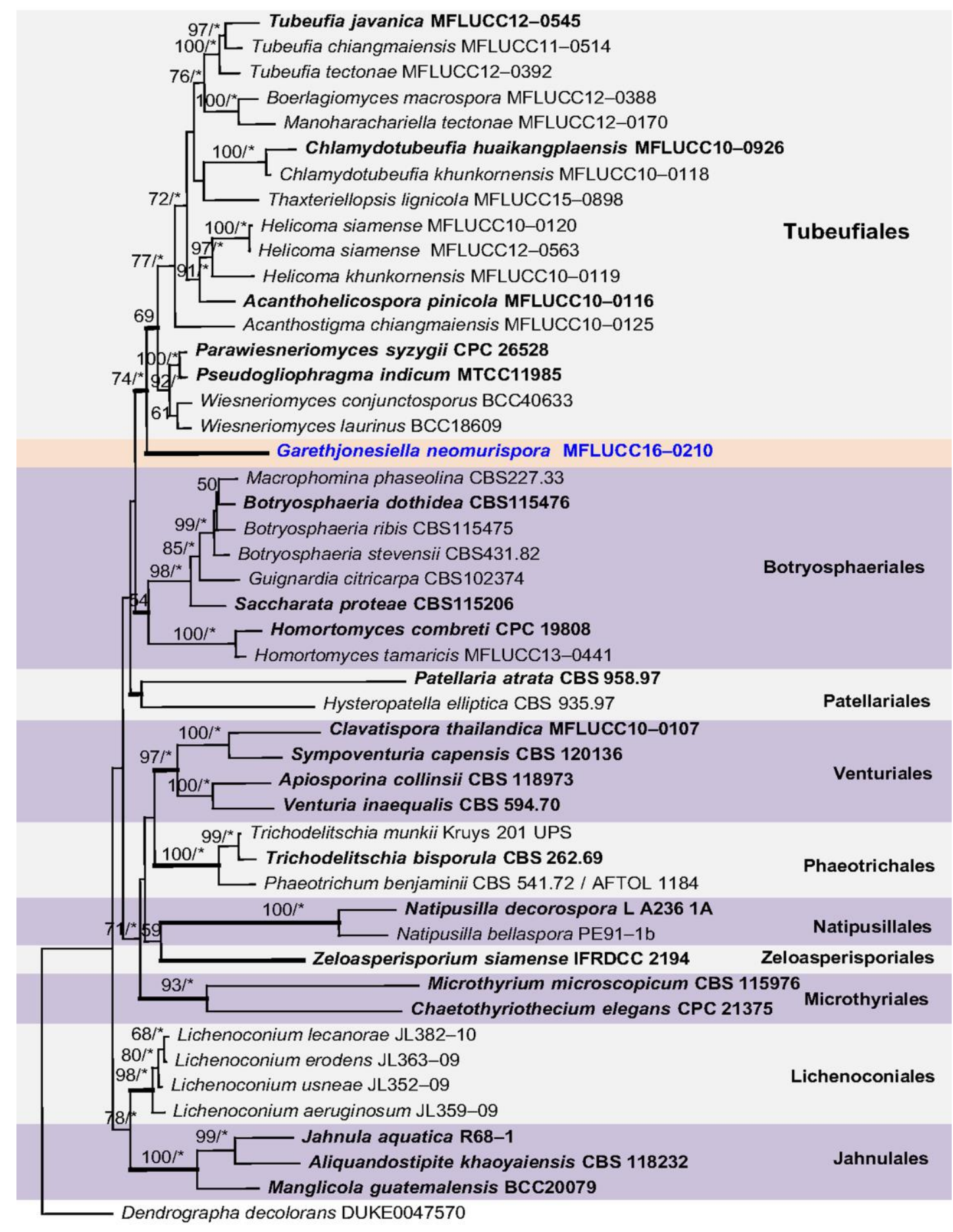

0.1

Fig. 1 Phylogram showing the best RAxML maximum likelihood tree $(\ln L=-22896.365251)$ generated from the combined multigene (LSU, SSU and TEF1 $\alpha$ ) analysis, with the GTRGAMMAI model, for showing the placement of the new genus Neorhamphoria and other closely related members of orders of Dothideomycetes. ML bootstrap values 1,000 repetitions with $\geqslant 50 \%$ (BS) are shown above the nodes and Bayesian posterior probabilities with $\geqslant 0.95(\mathrm{PP})$ are marked with an asterisk (*). The tree is rooted with Dendrographa decolorans (Turner \& Borrer) Ertz \& Tehler (Roccellaceae, Arthoniales). The new taxon in this study is highlighted in bold blue and all ex-type strains are in bold. 

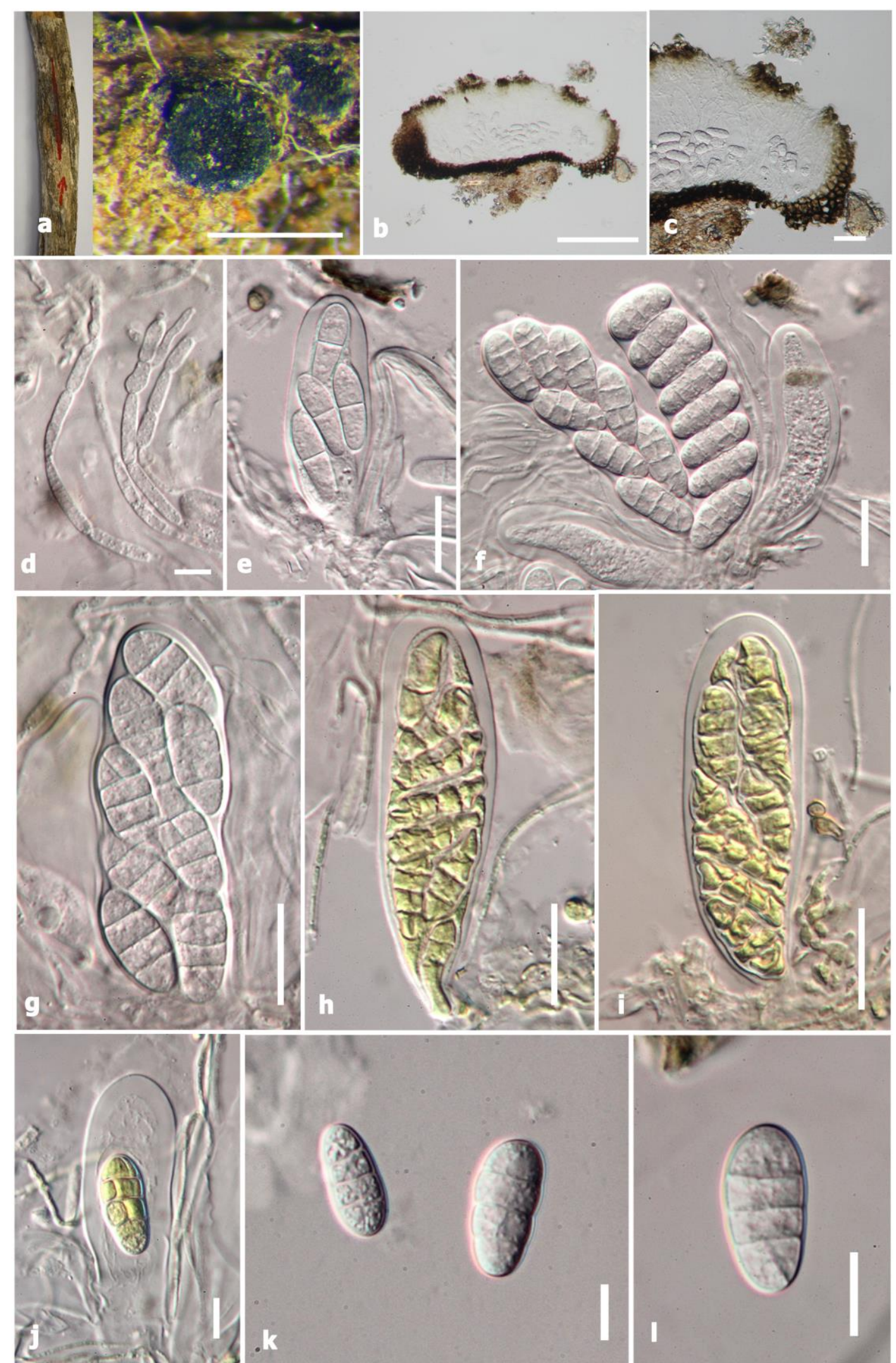

Fig. 2 Neorhamphoria garethjonesii (MFLU16-2859, holotype). a Type material and close up of ascoma. b Cross section of ascoma. c Peridium d Pseudoparaphyses e Immature ascus f,g Asci. h-j Asci and ascospores strained in Melzer's reagent. k, 1 Ascospores. Scale bars: a = $500 \mu \mathrm{m}, \mathrm{b}=200 \mu \mathrm{m}, \mathrm{c}=50 \mu \mathrm{m}, \mathrm{d}=5 \mu \mathrm{m}, \mathrm{e}-\mathrm{i}=20 \mu \mathrm{m}, \mathrm{j}-1=10 \mu \mathrm{m}$. 


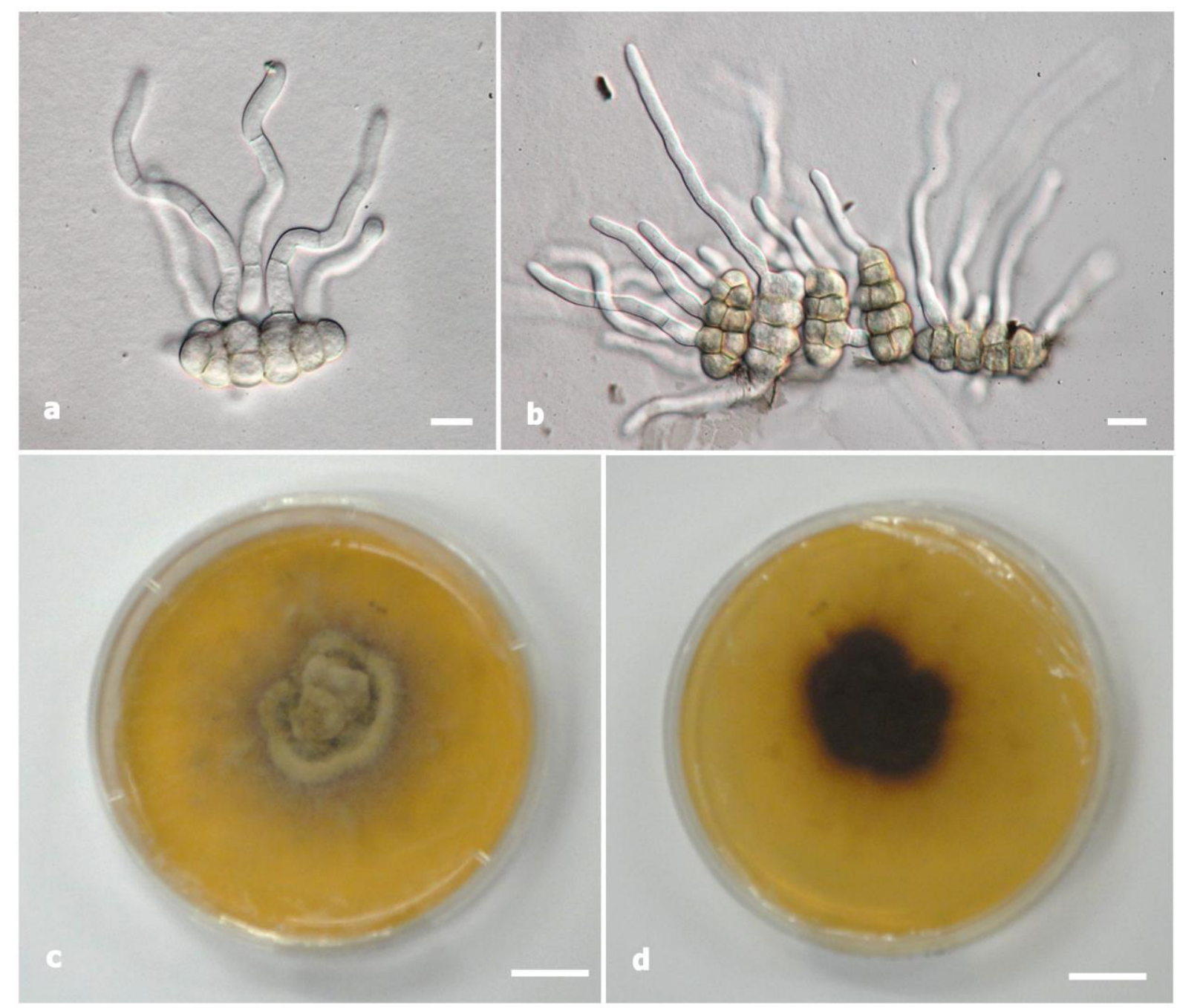

Fig. 3 Neorhamphoria garethjonesii (MFLU16-2859, holotype). a, b Germinating ascospores. c, d Colonies cultured on MEA from surface and reverse at 8 weeks. Scale bars: $\mathrm{a}, \mathrm{b}=10 \mu \mathrm{m}, \mathrm{c}, \mathrm{d}=10 \mathrm{~mm}$.

ascospores with 3-transverse septa and 1-2 vertical septa. Multigene phylogenetic analysis (LSU, SSU and TEF1 $\alpha$ ) shows that $N$. garethjonesii formed a clade at the base of Tubeufiaceae, while the clade of Patellariaceae is distant from Neorhamphoria garethjonesii (Fig. 1). According to overall morphological characteristics, the taxon given as $N$. garethjonesii differs from all tubeufiaceous genera. Therefore, we introduce this new genus to accommodate a monotypic species $N$. garethjonesii which we treat in Dothideomycetes genera incertae sedis.

\section{Discussion}

Neorhamphoria garethjonesii was first identified as a species of Rhamphoria as it appears to have unitunicate asci. However, a blast search and analysis of LSU, SSU and TEF1 $\alpha$ sequence data showed that it is related to dothideomycetous taxa. The blasted LSU and SSU sequences showed the new taxon to be loosely related to species of Chlamydotubeufia, Helicoma, Helicosporium, Tubeufia of Tubeufiales with 95\% to 96\% similarity, while TEF $\alpha$ sequence data showed it to be related to species of Alternaria, Bipolaris, Neofusicoccum and a Pleosporaceae sp. with $91 \%$ similarity. Analysis of LSU sequence data, placed Neorhamphoria close to Trypetheliales in a lineage basal to 
Patellariales, but this lacked good statistical support. The taxon was distantly related to Tubeufiales (tree not shown). Analyses of combined LSU, SSU and TEF1 $\alpha$ sequence data showed that Neorhamphoria clustered with Tubeufiales (Fig. 1). This genus is probably a basal genus or family related to Tubeufiales, however this cannot be confirmed until sequence data and more related taxa are available for study. Neorhamphoria is therefore treated in Tubeufiales, genus incertae sedis.

\section{Acknowledgements}

This work was funded by the grants of the Thailand Research Fund (project No. TRG5880152). Martina Réblová is thanked for sending plates of Rhamphoria for comparison.

\section{References}

Baydar S. 1975 - Erzurum, Erzincan ve Gümüşhane İllerinde Bitkilerden Toplanan Ascomycetes Fungusları Üzerinde Araştırmalar. Atatürk Üniversitesi Yayınları No: 411. Fen Fak. Yayınları No: 65, Araştırma Serisi 43, Atatürk Üniversitesi Basımevi, Erzurum.

Baydar S. 1982 - The fungus species of Ascomycetes collected from Trabzon and Rize Provinces. Atatürk Üniversitesi Fen Fak. Dergisi 1, 250-285.

Boonmee S, Zhang Y, Chomnunti P, Chukeatirote E et al. 2011 - Revision of lignicolous Tubeufiaceae based on morphological reexamination and phylogenetic analysis. Fungal Diversity 51, 63-102.

Boonmee S, Bhat JD, Maharachchikumbura SSN, Hyde KD. 2014a - Clavatispora thailandica gen. et sp. nov., a novel taxon of Venturiales (Dothideomycetes) from Thailand. Phytotaxa 176, 092-101.

Boonmee S, Rossman AY, Lui JK, Li WJ et al. 2014b - Tubeufiales, ord. nov., integrating sexual and asexual generic names. Fungal Diversity 68, 239-298.

Bülbül AS, Hüseyin E. 2013 - New records of microungi from Turkey (Bartın Province). Mycotaxon 125, 201-208.

Bülbül AS, Selçuk F, Hüseyin E. 2011 - New records of microfungi from Mt.Strandzha in Turkey (south-eastern Europe). I. Mycologia Balcanica 8, 161- 67.

Chomnunti P, Hongsanan S, Hudson BA, Tian Q et al. 2014 - The sooty moulds. Fungal Diversity 66, 1-36.

Crane JL, Shearer CA, Barr ME. 1998 - A revision of Boerlagiomyces with notes and a key to the saprobic genera of Tubeufiaceae. Canadian Journal of Botany 76, 602-612.

Davis PH. (edit.) 1967 - Flora of Turkey and East Aegean Islands. Vol. 2. Edinburgh University Press, Edinburgh.

Doilom M, Dissanayake AJ, Wanasinghe DN, Boonmee S et al. (2017) Microfungi on Tectona grandis (teak) in Northern Thailand. Fungal Diversity doi:10.1007/s13225016-0368-7

Erdoğdu M, Hüseyin E. 2008 - Microfungi of Kurtboğazı dam (Ankara and its enviroment). The Journal of Systematic Botany 14, 131-150.

Göbelez M. 1963 - La Mycoflore de Turquie. I. Mycopathologia et Mycologia Applicata 19, 296-314.

Glez-Peña D, Gómez-Blanco D, Reboiro-Jato M, Fdez-Riverola F et al. 2010 - ALTER: program-oriented format conversion of DNA and protein alignments. Nucleic Acids Research 38, 14-18. 
Güven K, Tamer AÜ. 1993 - Some parasitic fungi determined in plants living in Eskişehir. Journal of Faculty of Science Ege University B 15, 25-31.

Hamzaoğlu E. 1996 - Kervansaray dağının (Kırşehir) florası. Ot sistematik botanik dergisi 3, $1-24$.

Hall TA. 1999 - BioEdit: a user-friendly biological sequence alignment editor and analysis program for Windows 95/98/NT. Nucleic Acids Symposium Series 41, 95-98.

Hongsanan S, Tian Q, Bahkali AH, Yang JB et al. 2015 - Zeloasperisporiales ord. nov., and two new species of Zeloasperisporium. Cryptogamie Mycologie 36, 301-317.

Hüseyin E, Bülbül AS, Akgül H. 2009 - Some notes on micromycetes from Turkey. Pakistan Journal of Botany 41, 453-459.

Hüseyin E, Selçuk F. 2016 - Pileolaria azerii (Uredinales), a new rust species from Turkey. Sydowia 68, 1-6.

Hüseyin E, Selçuk F, Ekici K. 2016 - Acrodictys, Corynespora, Karstenula, Oncopodium, and Sporocadus: new genera for Turkey. Mycotaxon 131, 331-335.

Hüseyin E, Selçuk F, Şahin A, Erdoğdu M. 2006 - New records of ascomycetous microfungi species for Turkey. Plant, fungal and habitats diversity investigation and conservation. IVth Balcan Botanical Congress. Book of Abstracts. Sofia.

Hüseyin E, Yıldızbaş M. 2005 - Some micromycetes on oak (Quercus) in Karaman Province of Turkey. Proceedings of the XVI Symposium of mycologists and lichenologists of Baltic States. Cesis.

Hüseyinov E, Selçuk F. 2001 - Contribution to study of mycoflora of Turkey. II. Ascomycetous and Basidiomycetous microfungi of forest trees and shrubs in the Black Sea coast (Rize Province). Mikologia i Fitopatologia 35, 13-15.

Hüseyinov E, Selçuk F. 2000 - Türkiye de bulunan ve bulunması muhtemel Sphaerotheca Lév. Genusu türleri ile ilgili bir rapor. Journal of Qafgaz University 6, 159-166.

Hyde KD, Hongsanan S, Jeewon R, Bhat DJ et al. 2016 - Fungal diversity notes 367-490: taxonomic and phylogenetic contributions to fungal taxa. Fungal Diversity 80, 1-270.

Jayasiri SC, Hyde KD, Ariyawansa HA, Bhat JD et al. 2015 - The faces of Fungi database: fungal names linked with morphology, phylogeny and human impacts. Fungal Diversity 74, 3-18.

Karaca İ. 1961 - A Research on Erysiphaceae of Turkey. Atatürk Üniversitesi Y1llığı.

Katoh K, Standley K. 2013 - MAFFT Multiple Sequence Alignment Software Version 7: Improvements in Performance and Usability. Molecular Biology and Evolution 30, $772-780$.

Kirk PM. 2016 - Index Fungorum Partnership: Index Fungal. http://www.indexfungorum.org/Names/Names.asp. Accession Date 19 December 2016

Kodsueb R, Jeewon R, Vijaykrishna D, McKenzie EHC et al. 2006 - Systematic revision of Tubeufiaceae based on morphological and molecular data. Fungal Diversity 21, 105130.

Mel'nik VA, Hüseyin E, Selçuk F. 2004 - Contribution to the studying of micromycetes in several Black Sea provinces of Turkey. Novitates Systematicae Plantarum non Vascularum. Nauka. Petropolis 37, 133-148.

Miller MA, Pfeiffer W, Schwartz T. 2010 - Creating the CIPRES Science Gateway for inference of large phylogenetic trees. In: Proceedings of the Gateway Computing Environments Workshop (GCE). San Diego Supercomput. Center, New Orleans.

Niess1 von G. 1876 - Notizen uber neue und kritische Pyrenomyceten. Verhandlungen des Naturforschenden Vereines in Brünn 14, 165-218. 
Page RDM. 2001 - Tree View: tree drawing software for Apple Macintosh and Windows. http://taxonomy.zoology.gla.ac.uk/ rod/treeview.html

Pratibha J, Nguyen HDT, Mel'nik VA, Bhat DJ et al. 2015 - Lectotypification, epitypification, and molecular phylogeny of the synnematous hyphomycete Pseudogliophragma indicum, the second genus in the Wiesneriomycetaceae. Mycoscience 56, 387-395.

Promputtha I, Miller AN. 2010 - Three new species of Acanthostigma (Tubeufiaceae, Dothideomycetes) from Great Smoky Mountains National Park. Mycologia 102, 574587.

Rajeshkumar KC, Sharma R. 2013 - Tamhinispora a new genus belonging to family Tubeufiaceae from the Western Ghats, India based on morphology and phylogenetic analysis. Mycosphere 4, 165-174.

Réblová M, Barr M 2000 - The genus Acanthostigma (Tubeufiaceae, Pleosporales). Sydowia $52,258-285$.

Ronquist F, Huelsenbeck JP. 2003 - MrBayes 3: Bayesian phylogenetic inference under mixed models. Bioinformatics 19, 1572-1574.

Selçuk F, Hüseyin E. 2014 - New records of microfungi from Mt. Strandzha in Turkey (southeastern Europe). II. Mikologia i Fitopatologia 48, 202-208.

Selçuk F, Hüseyin E, Şahin A. 2010 - Contribution to Study of Turkey Mycobiota. IV. The new records of microfungi with asci to forest phytocoenose of Rize Province. Artvin Coruh University Faculty of Forestry Journal 11, 53-60.

Suetrong S, Rungjindamai N, Sommai S, Rungareerate P et al. 2014 - Wiesneriomyces a new lineage of Dothideomycetes (Ascomycota) basal to Tubeufiales. Phytotaxa 176, 283297.

Villesen P. 2007 - FaBox: an online tool box for fasta sequences. Molecular Ecology Notes 7, 965-968.

Wijayawardene NN, Hyde KD, Camporesi E, Bhat DJ et al. 2014 - Homortomyces tamaricis sp. nov. and convergent evolution of Homortomyces and Stilbospora. Phytotaxa 176, $156-163$.

Yacharoen S, Tian Q, Chomnunti P, Boonmee S et al. 2015 - Patellariaceae revisited. Mycosphere 6, 290-326. 